\title{
A Study To Analyze Impact Of Insolvency And Bankruptcy Code 2016 On NPA's Of Commercial Banks With Reference To Iron And Steel Sector
}

\author{
Arti Chandani ${ }^{1}$, Rajiv Divekar ${ }^{2}$, Abdus Salam $^{3}$, Mita Mehta $^{4}$ \\ \{ arti.chandani@sims.edu ${ }^{1}$,director@sims.edu², abdus.salam2020@sims.edu ${ }^{3}$, \\ mita.mehta@sims.edu $\left.{ }^{4}\right\}$
}

Symbiosis Institute of Management Studies, Symbiosis International (Deemed University), Pune, MH, India ${ }^{1,2,3,4}$

\begin{abstract}
Indian banking sector is going through a tough phase where the GNPA (gross Non-performing assets) are all time high and there seem to be no respite in this coming quarter, at least. An asset is classified as NPA (Non-Performing Assets) which ceases to generate income for a bank. The gross Non-performing asset ratio stood at $11.5 \%$ in March, 2018 and this could reach to $12.2 \%$ by March 2019 (RBI financial stability report). There seems to be some respite on this increase where GNPA declines from 11.5\% in March 2018 to $10.8 \%$ in September, 2018 (RBI financial stability report). India has seen various debt resolution mechanism namely BIFR (Board for Industrial and Financial Reconstruction), CDR (Corporate debt restructuring), SARFAESI (Securitization and reconstruction of financial assets and Enforcement of Securities Interest) Act, 2002 to IBC (Insolvency and Bankruptcy Code) in 2016. Insolvency and bankruptcy code (IBC) 2016 was enacted in India in May 2016 with the intent of providing a solution which is efficient and time bound. The code has a time frame of 180 day and extension of 90 days which makes a total of 270 days for a company to "resolve or liquidate". Immediately after passing resolution of IBC in Parliament in May, 2016, NCLT (National Company Law Tribunal) was constituted on 1st June, 2016. It started receiving cases of insolvency and bankruptcy from end of 2016 and presently NCLT has 11 benches through which it operates. IBC and NCLT operate under IBBI (Insolvency and Bankruptcy board of India) which was established on 1st of October, 2016. IBBI regulates and supervises professional, agencies, and entities related to insolvency along with information utilities. IBBI has also been entrusted to enforce rules related to corporate insolvency resolution, corporate liquidation, individual bankruptcy and individual insolvency resolution. IBC has been instrumental, so far, in bringing a much needed change in the credit discipline of the borrowers. It is expected that given the time-bound resolution, it will help banks to recover its loan faster along with controlling the losses which occur due to passage of time. The present study focuses on the loans and advances extended to Iron and Steel companies in India and performance of these loan over a last decade. Iron and steel sector contributes to $24 \%$ of the GNPA in basic metal and metal product category as on January, 2018. Due to mounting pressure on the service of the loans for Iron and steel industry, the growth of bank credit to iron and steel sector fell to $2.5 \%$ in 2017 , which is all time low. The gross bank credit to Iron and Steel sector stood at Rs. 2,908 billion as of November, 2018. The total default of Rs. 570.01 billion has been admitted under IBC 2016 as on December, 2018. The study focuses on the trends of bank credit to this sector along with recovery and default in Iron and steel sector. The total of Rs. 1,288 billion defaults were with IBC 2016 and around $44 \%$ of the default is coming from Iron and Steel sector. The study will focus on few cases of the companies which have been declared as insolvent such as Monnet
\end{abstract}


Ispat, Electrosteel to name a few. The study is aimed to understand the major reasons of default for Iron and steel sector.

Keywords: Insolvency and Bankruptcy Code, 2016, Non-performing assets, Iron and steel sector, Liquidation, National Company Law Tribunal

\section{INTRODUCTION}

\subsection{Banking System}

Banking sector plays a very significant role in the growth and development of nation and it is considered as the backbone of any industry. The financial sector reforms as led by Shree M. Narasimhan Committee in 1991, the banking system of India has undergone significant transformation with a vision and mission to boost the banking sector and its operations in the economy.

The Indian Banking System comprises of Scheduled and Non- Scheduled banks. Schedules banks are included under the 2nd Schedule of Reserve Bank of India, Act 1934, where it is further classified into nationalized banks; State Bank of India and its associates; Regional Rural Banks (RRBs); foreign banks; and other Indian private sector banks. The term commercial banks refer to both scheduled and non-scheduled commercial banks regulated under the Banking Regulation Act, 1949.

\subsection{Definition of Banking}

As per Section 5(b) of the Banking Regulation Act, 1949, "banking" means the accepting, for the purpose of lending or investment, of deposits of money from the public, repayable on demand or otherwise, and withdrawable by cheque, draft, order or otherwise. The main functions of banks are to accept deposits from the public and lending the money for the purpose of investment or loan.

\subsection{Non- Performing Asset}

The concern of NPA for any country is very deep and global. But for the developing countries like India, the magnitude of this concern is undoubtedly very high. The economic reforms led by the Indian government to match the speed of global economic challenge cannot be achieved without the complete and strategic overhaul of Indian banking and financial sector. The problem of NPAs is continuously growing which is threating banks existence, shrinking their profitability and affecting the economy in general. Non-performing assets is termed as the loan or lease that does not meet the stated principal amount and the interest amount payments. NPA is further classified into commercial loans which are overdue for more than 90 days, and consumer loans which are due for more than 180 days.

\subsection{Definitions of NPA}

An asset is termed as non-performing asset when it stops producing income and profit of the bank and this can happen due to leased assets or for a loan or advance extended by banks. In case of a loan or advance when the interest or installment is overdue for more than 90 days, it is termed as NPA. 
The NPAs of the bank can be classified into following categories:

1. Gross NPA: It is the amount of all the NPAs which are shown on a given date. Gross NPA includes all the assets which could be sub-standard, doubtful and loss assets.

2. Net NPA: It is the amount of NPAs for which bank has provided provisions for it. It is the real burden of any bank. The difference between Gross NPA and Net NPA is on the account of the provisions made by the bank.

\subsection{Overview of Iron \& Steel sector}

Steel plays a very important role in the growth of developing countries like India. Being a core sector, steel is important to the country's economic security as it is extensively used in a variety of areas such as social and economic infrastructure, defense, automobiles etc. Total crude steel production in India has elevated at a CAGR of 5.43 per cent during FY12-18, with country's output reaching 103.13 million tonnes per annum (MTPA) in FY18. The country is the third largest crude steel producer in 2017, as both public and private sector players' escalated steel production in view of rising demand. The capacity has increased to 137.98 million tonnes (MT) in 2017-18 while in the coming ten years the figure is expected to appreciate to 300 MT of steel. In FY18, India produced 104.97 million tonnes (MT) and 103.12 MT of finished steel and crude steel, respectively. India was also a net exporter of steel in FY18. Exports and imports of finished steel were at 4.33 MT and 5.41 MT, during Apr-Nov 2018 (P).

Steel consumption is anticipated to grow 7.5 per cent year-on-year to 95.4 MT in 2018. India's steel production is forward to increase from 103.13 MT in FY18 to 128.6 MT by 2021. India's expected growth in consumption is due to growing infrastructure construction, automobile and railway sectors. National Mineral Development Corporation is expected to compound the iron ore production 75 million tonnes per annum (MTPA) until 2021 indicating new room in the sector. Demand would be mainly due to growth in the domestic market. Infrastructure, oil and gas and automotive are the main drivers of growth in the industry. To attain steel capacity buildup of 300 million tonnes per annum (MTPA) by 2030, India is require to invest US\$156.08 billion by 2030-31 market.

The steel industry is considered as the largest contributor to the banking systems nonperforming assets (NPAs). The top 5 steel companies contributing to the list of NPA s are Essar Steel, Monnet Ispat, Bhushan Steel, Electrosteel Steels and JSPL The add up debt of the five companies stood at ₹ 1482.89 billion at March-end 2016, with a stressed advances ratio of 45.8 per cent

Answering a question in Lok Sabha, minister of Steel mentioned that contribution of Indian steel industry to GDP is approximately $2 \%$ as per National Steel Policy, 2017.

\subsection{Insolvency and Bankruptcy Code 2016}

Currently there are multiple overlapping laws which deals with financial failure and insolvency of companies and individuals in India. The present legal and institutional framework does not aid lenders in effective and timely recovery or restructuring of defaulted assets and causes undue strain on the Indian credit system. The framework tried to bring in an element of time-bound and systematic resolution of insolvencies for maximization of value for all stakeholders and balancing of information asymmetry besides protection of interest of all stakeholders. 
In the year 2000, the level of NPAs rose drastically. During the year 2008 to 2014, Banks lent indiscriminately that led to a very high percentage of NPAs which was highlighted by the Asset Quality Reviews of the RBI and this led to a prompt action by the Government. A Committee was formed, which submitted its Report in 2015 recommending the IBC and immediately, a Bill was introduced in Lok Sabha and referred to a Joint Committee of Parliament. On 5 May, 2016 IBC was approved by both Houses of Parliament and received the assent of the President of India on 28 May 2016.

\section{LITERATURE REVIEW}

Julian R. Franks, Kjell G. Nyborg, and Walter N. Torous in their paper "A Comparison of US, UK, and German Insolvency Codes" (1996) compare the efficiency of Insolvency codes in these countries with some certain benchmarks. These codes have been selected because they cover a wide spectrum of debtor and creditor-oriented insolvency problems. The authors have evaluated efficiency at three stages in the bankruptcy process - ex ante, interim, ex post. The author gives a small description about the insolvency codes of all the 3 countries presented at the top. They are actually compared with reference to 9 prominent characteristics. In the end the author concludes by stating the significance of all the three Insolvency codes.

C.S. Balasubramaniam in his paper "Non-Performing Assets and Profitability of Commercial Banks in India: Assessment and Emerging Issues" (2011) described the concept of NPA and its impact on financial soundness of general banks; it also presented a trend analysis of NPAs and in deep as saying on the lofty level of borrowings from banking sector. The final part deals on the significance of restructuring of advances and the Basel III norms. It has also mentioned the impacts of NPA on the operation of banks and it has been divided to profitability, liquidity, involvement of management, credit loss. The NPAs under priority sector has decreased mainly from the contribution of agriculture sector due to the debt waiver schemes for farmers and the sudden increase in non-priority sector is due to the slowdown in the economy and stressed financial conditions of corporates. The asset quality of banking sector has improved mainly because of the written off of the outstanding gross non-performing loans which helped in restricting the growth of NPAs.

Dr. Suresh Vadde, G. Srinivas in their paper “The Indian Steel Sector: Development and Potential" (2012) studied the present global scenario of steel industry and especially in the perspective of Indian context, they also studied the development in production of Crude steel in both private and public sector and in the end he has highlighted the challenges faced by the industry. From the secondary data collected from 2005-2011 of the Annual reports of different steel sectors it is seen that there is a rapid pace in growth of the steel industry and sharp increase in the demand prospect as well. The private sector is majorly indulged in new technological aspects and the mergers by some companies has started to show fruit in the sector. In the end author also has mentioned some challenges like cost of power and non-availability of metallurgical coke, also the high cost of capital because of high interest charged for steel industries. Poor infrastructure facilities like poor quality of road, port are also some challenges.

Dr S.M.Tariq Zafar, Dr Adeel Maqbool, S.M.Khalid in their paper "Non-performing Assets And Its Impact On Indian Public Sector Banks"(2013) dealt with strategic overview of the NPA problem and emphasize its magnitude, actual causes behind rearing and addressing NPAs 
in Indian PSBs. It also tries to analyze the impact of NPA"s in general and to analyze the impact of SARFAESI Act implemented with amendment. According to the authors research it was found that the directed loans system below which commercial banks are bound to prescribed percentage of their credit (40\%) to priority sectors as one of the main reasons of NPAs into banking sector and it was also found that loans are provided by them to different industrial houses not on commercial considerations and viability of project instead on political considerations, affiliations and associations, without making a thorough study of the facts, real need of the party concerned, its past records, its managerial skills, the prospects of the business in which it was and is engaged, and so on.

Ashly Lynn Joseph, Dr. M. Prakash in their paper "A Study on Analyzing the Trend of NPA Level in Private Sector Banks and Public Sector Banks" (2014) studied about the early warning signals system of banks and the provisions made for four different asset categories in the banks. The author has collected data for 6 years from 2008 to 2013. From the data, the amounts of doubtful advances have been increasing year by year for both public and private banks. The author has also collected the data of the composition of NPAs of nationalized banks and from that study it's been concluded that initially the NPAs weighted percentage was high in priority sector compared to non-priority sector but as year passes the condition has reversed as non-priority sector leads over the priority sector in the NPA percentage.

Sulagna Das and Abhijit Dutta in their paper "A Study On NPA of Public Sector Banks In India“" (2014) analyzed 26 public sector Banks with the aid of secondary data from RBI regarding the net non-performing assets for the past 6 years. The paper also helps us to derive the important contrast of the NPA occurrence, and management of NPA in different nationalized banks of India in respect to priority and non-priority sector lending. In the paper author conducted Anova one-way statistical tool in which he found out that there is a revelatory difference in mean variation between the NPAs of the banks and in the end it is found out that there is no eloquent difference between the means of NPA of the banks at five per cent level of significance.

Laveena in her paper "A Study of Non-Performing Assets of Public Sector Banks in India" (2016) how the economies are affected by NPAs and comprehending the reasons of it and discussed about the importance of its effects. The author has segmented the factors into two headings internal and external. The author has also tried to equate the performance of public sector banks and private sector banks in India. According to the RBI data the NPA s are accelerating in the public sector banks as to private sector banks and its having an adverse effect in their operational activities. The author also studied the causes of account becoming NPA and highlighted that in the perspective of a borrower and banks.

Javish Valecha, Ankita Anupriya Xalxo in their paper "Overview of The Insolvency and Bankruptcy Code, 2016 \& The Accompanying Regulations" (2017) explains about the different facets about the Insolvency and Bankruptcy Code 2016 (New Code). Initially the author explains about the flaws in the existing regime and has segmented that into different sections. Then later explains about the new code and corporate insolvency, its scope of applicability, its legal considerations and the recent developments.

Dr. Raj Kumar Mittal and Ms. Deeksha Suneja in their paper "The Problem of Rising NonPerforming Assets in Banking Sector in India: Comparative Analysis of Public and Private Sector Banks" (2017) attempted to first determine the level of NPAs in the Indian banking 
sector and then tried to find out the causes for increasing NPAs. The author has also tried to study the magnitude of increase in NPA $\mathrm{s}$ in public sector banks as compared to private sector banks. The author has also analyzed the reasons for increasing NPAs in banks in India and the methods to reduce the NPA's level. The author has collected the secondary data from RBI websites between the years 2005-2016 to analyze these objectives. The major impacts like liquidity problem, higher cost of capital, declining productivity has been explained. The authors also study about the various recovery methods like SARFAESI Act, Debt Recovery tribunals and LokAdalats etc.

Dr. Mohammad Miyan in his paper "A Comparative Statistical Approach towards NPA of PSU and Private Sector Banks in India" (2017) studies about various parameters like Gross NPA $\%$, Net NPA $\%$, return $\%$ on assets, growth $\%$ of Net NPA and growth $\%$ of return on assets of State Bank of India, Punjab National Bank, HDFC Bank, ICICI Bank. The ratio components mentioned above has been analyzed through mean, coefficient of variation, coefficient of correlation, CAGR and t-test of significance. The data was collected from annual reports, magazines, books and journals. The period is from 2011-2016.

Shipra Bhatia in her paper "Crisis in Indian Steel Industry: Issues and Challenges” (2017) studied the current status of Indian Steel Industry, the trends in production and consumption, installed capacity and utilization, the current tide in exports and imports in steel industry, Influence of international demand and supply factors on the Indian Steel industry. In the paper the secondary data has been collected from the year between 2012 and 2015, the production growth actually witnessed a declining trend, mainly due to the muted demand from the construction and automobile sectors and in terms of per capita consumption steel, India stands at $63 \mathrm{~kg}$ as against the world average of $225 \mathrm{~kg}$, indicating a huge potential in the industry. From the data collected from Import and Export India has mainly been a net importer of steel in the last few years. But instead 2016-17, the table has turned as India became net-exporter of steel after a gap of three years. In the closing few periods steel exports from India elevated by over 100 per cent to $8.2 \mathrm{mt}$ while imports fell by 36 per cent to $7.4 \mathrm{mt}$.

Subhadip Choudhuri in their paper "Should the Insolvency and Bankruptcy Code Be Shadowed by Limitation" (2017) is focused on the applicability of the 'Limitation Act '1963 on the Insolvency and Bankruptcy Code, 2016. The paper also focusses on the different types of Insolvency Laws in India along with the basic features of corporate insolvency and the various recommendations made by the Balakrishna committee. It also talks about the main controversy behind the applicability of the Limitation Act and how it originated. The reasons why some statutes are not covered by the Limitation Act has also been explained. Lastly, the paper deals with whether the National Company Law Appellate Tribunal was right in exempting the Insolvency and Bankruptcy Code' 2016 from the shackles of the Limitation Act' 1963.

Sreyan Chatterjee, Gausia Shaikh and Bhargavi Zaveri in their paper "Watching India's insolvency reforms: a new dataset of insolvency cases" (2017) discusses about the new dataset of orders passed by the National Company Law Tribunal (NCLT) in the insolvency cases under the Insolvency and Bankruptcy Code or IBC. There are about 23 areas of information recorded in the new dataset. The authors are showing their interest by attempting an empirical analysis on the economic effect of IBC and the performance of judiciary which is under the IBC. The author analyzed the orders of the provisions of the IBC during the first 6 months of 
operationalization and were able to find behavioural shifts among credit market participants within a short time from passing the law with the help of limited dataset.

Richa Barnerjee, Deepak Verma and Dr. Bimal Jaiswal in their paper "Non-Performing Assets: A Comparative Study of the Indian Commercial Banks" (2018) has analyzed the impact on the asset quality of the Indian banks due to the presence of NPAs. The author has also compared the ROA selected private and public sector banks. The author has taken data of 4 banks to conduct the study. The 4 banks are: SBI, PNB, AXIS Bank and HDFC Bank. The Gross NPA and Net NPA have been showing an increasing trend for both SBI and PNB and it has been moderate for other 2 banks. The Asset Quality management is best for AXIS Bank followed by HDFC. The ROA is best for HDFC Bank

Dr. Sangeeta Kumar in her paper "A Study on Non-Performing Assets of Indians Banks: Trend and Recovery" (2018) has collected data from the past 17 years from 2000-2017 of Gross NPA and Net NPA. The trend produced a result that shows the Net NPA has decreased from 2000 to 2005 mainly due improvement in the setting up of Asset Reconstruction Corporation of India, which provided a major boost to recover NPAs. After that there is a significant increase in NPA mainly due to the hardening of interest rates and lending indiscriminately during these years. The author has also collected data of recovered NPA through Lok Adalats, DRTs and SARFAESI Act, the study shows that the percentage of recovered amount is decreasing that is decreased from $23 \%$ in 2012 to $10 \%$ in 2017 . The deceleration in recovery was mainly due to a reduction in recovery through the SARFAESI channel. Because of assets reconstruction companies (ARC's) Indian banks is able to reduce their stressed assets by selling to them.

\section{RESEARCH GAPS}

The authors have done extensive research on the topics related to the theme of the paper and these were sub-divided into search topics such as "NPAs of banks", "NPAs in Iron and steel sector", "Insolvency and bankruptcy Code", "Loans given to Iron and Steel Sector". The research which is available is in the area of "NPAs and performance of banks" and very little research is available in the area of "Loans and performance of Iron and Steel Sector". The authors could not find research in the area of "Insolvency and Bankruptcy code" barring one research which has been done in the year 2017 where the researchers focused on the legal status of IBC and NCLT. Based on this the authors have listed the following gaps which are existing:

1. There is not much research done in the NPAs of the bank in the area of Iron and steel sector

2. There is dearth of research in the functioning and performance of IBC, 2016

3. There is not much research done to analyze the progress made by IBC, 2016

\section{OBJECTIVES OF THE STUDY}

- To identify and examine the emerging trends of NPAs

- To study Insolvency \& Bankruptcy code, 2016. 
- To find out amount of outstanding loan and number of cases under IBC for Iron \& Steel Industry.

- $\quad$ To find out impact of IBC, 2016

\section{RESEARCH METHODOLOGY}

\subsection{Research type: -}

The present study is exploratory research where the researchers have explored the NPAs of the bank for the period of last 10 years. The researcher have also studied the exposure of the banks during the study period to the total industries as well as to the iron and steel industry.

\subsection{Time Period}

The present study covers last year data starting from financial year 2008 to financial year 201718.

\subsection{Source of Data}

The study is primarily based on the secondary data where data has been collected, collated and compiled from various RBI annual reports, websites like IBBI and NCLT, books, journals, and various research papers. The authors have also studied various reports published by KPMG, Mckinsey, Deloitte and EY.

\subsection{Sample Selection}

The authors have chosen private sectors as well as public sector banks to study the NPAs of these banks for last 10 years. The authors have focused on the iron and steel sector as there have been more defaults to the banks and this sector is one of the biggest NPAs for these banks.

\section{DATA ANALYSIS}

The researchers have collected data from various secondary sources including RBI publication, CMIE-Prowess, banks website, IBBI website among others. The researchers have collected data in order to present the situation of the NPAs of the banks and more importantly NPAs to the iron and steel sector. The time period for such analysis is last 10 years starting from FY 2008 to FY 2018. 


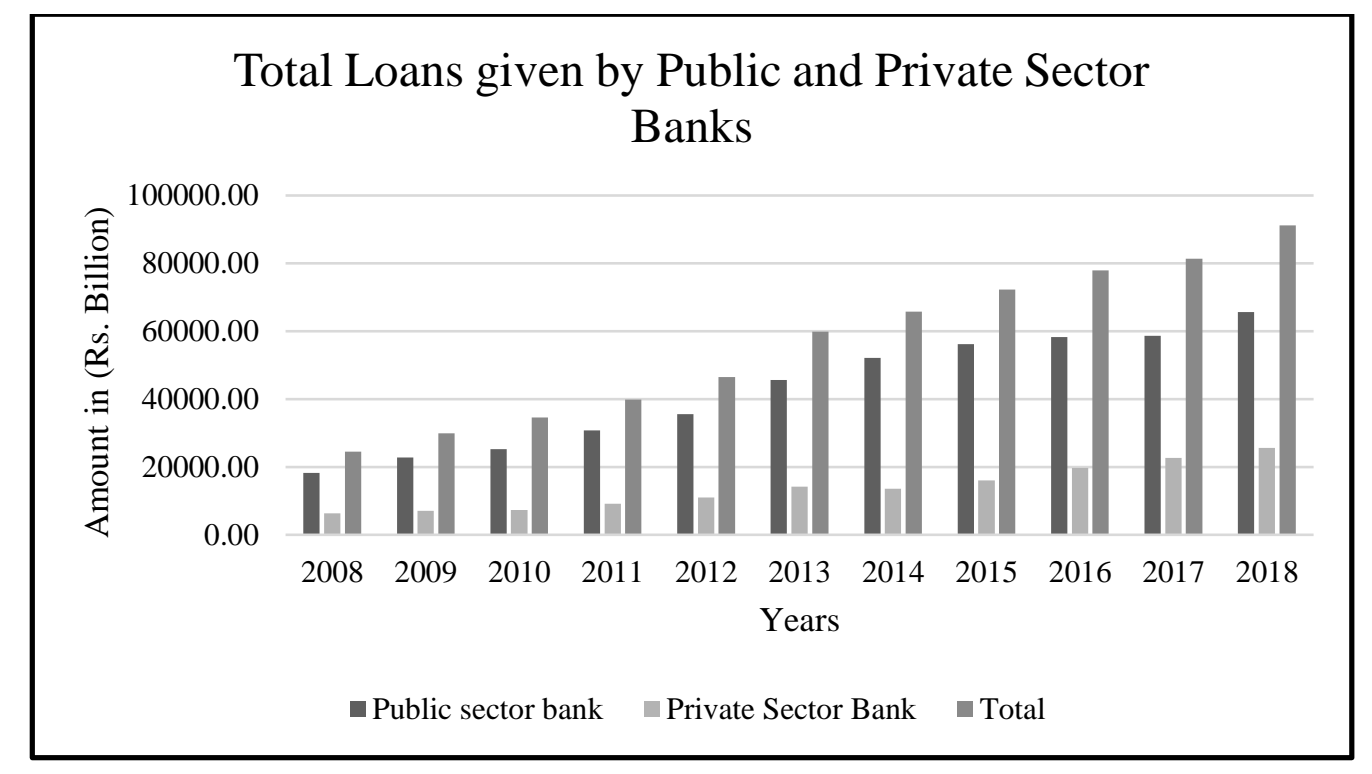

Figure 1: Total Loans given by Public sector banks and private sector banks to all the industries. (Source: https://m.rbi.org.in/Scripts/PublicationsView.aspx?id=18523)

The total loans given by the public as well as private sector has seen an upward trend since 2008 and this is in line with the growth of the economy when the country and economy is growing there is demand created from the various industries to meet that demand. This results in demand in the monetary requirement from the industries and therefore there is an upward trend in the loans given to these industries. If we analyze the growth in the loan on y-o-y basis, it was $21.69 \%$ from FY 2007-08 to FY 2008-09. The highest growth was recorded in the FY 2012-13 where the loan given increase to $28.56 \%$ in comparison to FY 2011-12 and since then the loans given has recorded a negative growth. The growth in the loan given was in single digit from FY 2013-14 to FY 2018-18. The lowest growth was in the FY 2016-17 where the loans given grew at $4.34 \%$ in comparison to FY 2015-16.

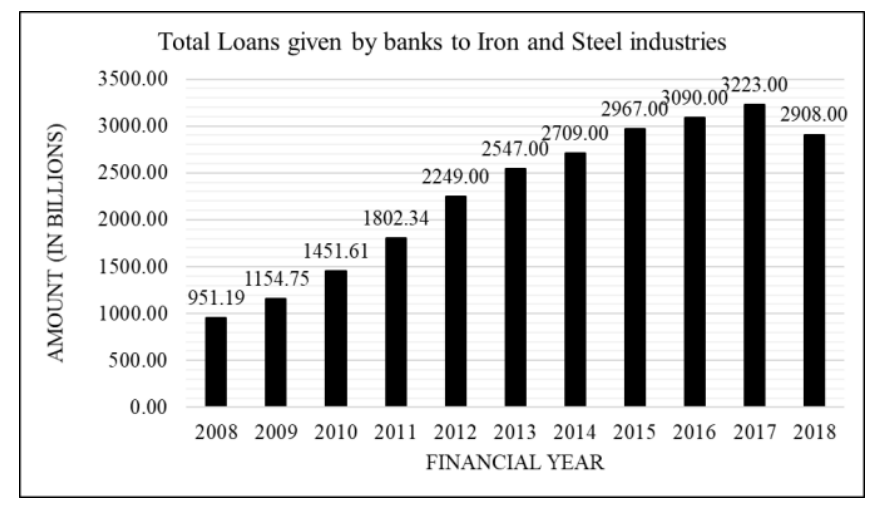

Figure 2: Loans given by Public Sector banks and Private sector banks to Iron and Steel Sector ( Source: https://rbi.org.in/Scripts/Data_Sectoral_Deployment.aspx) 
The amount of loan given to Iron and steel sector was $3.87 \%$ in the year 2008. Iron and steel sector is a part of mineral sub-section of industries as per the reporting format of the banks. The loans to Iron and steel sector were highest in the year 2012 where the total percentage was $4.83 \%$ and post that it started declining and the figure stood as $3.96 \%$ in the year 2017 . The lowest loan to iron and steel sector was in FY 2017-18 where the percentage stood at $3.36 \%$ of the total loans and the absolute amount stood as Rs. 86507.14 billion.

Under the heading current financial distress in the steel sector the author presents the data of subdued financial performance of the Indian steel companies. Falling profits and rising debts has been their main concern (Bhatia, 2017).

If you take the sector wise snapshot the companies from the metal industry has the highest outstanding debt which sums up to 1540 billion, the second in the list is technology media were the value sums up to 0.5 billion. Total cases registered under IBC in metal industry is 74 which is the highest compared to other sectors (source: RBI Report)

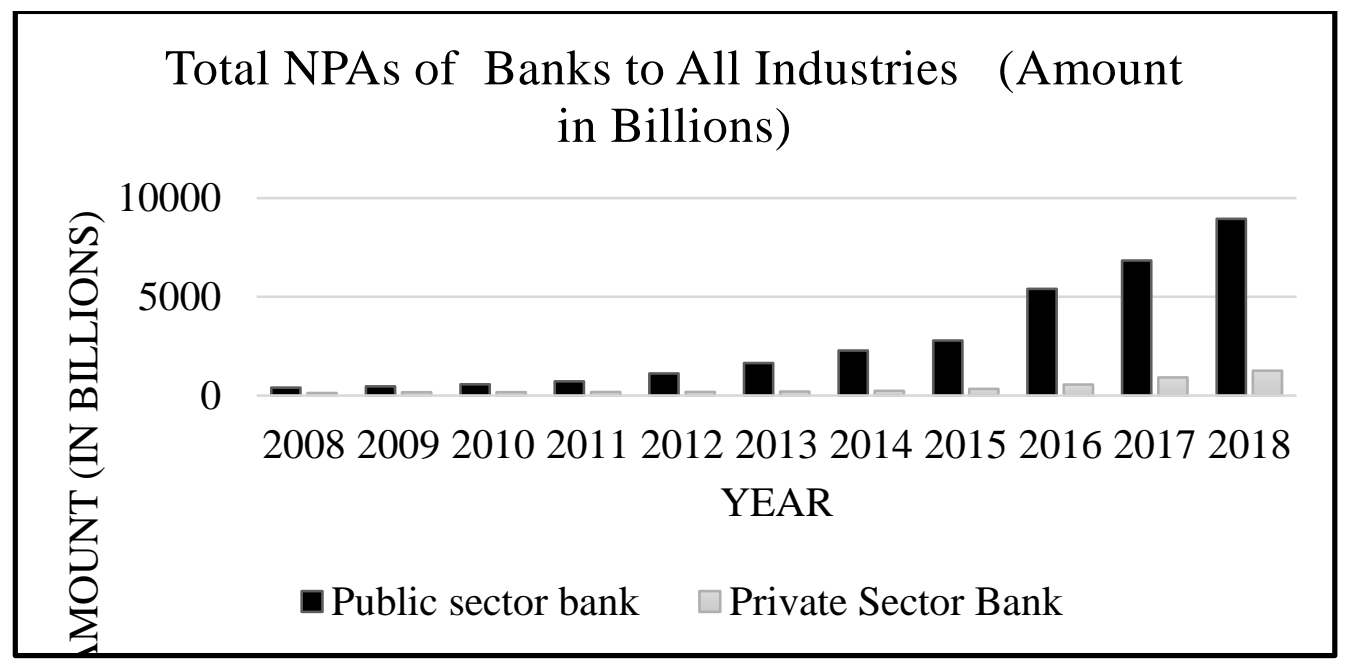

Figure 3: NPAs of the Public sector banks and private sector banks (Source: https://dbie.rbi.org.in/DBIE/dbie.rbi?site=publications\#!4:)

The figure 3 shows the NPAs of the banks to the all the industries for private as well as public sector banks. The figure 3 clearly highlights the importance of the mechanism in which loans are given and governed. The private sector is operating in the same macro environment and the same eco system but it has remarkably low NPAs than the public sector banks. The total NPAs of the bank stood as $11.21 \%$ in FY 2017-18 where the share of Public sector banks was more than $14 \%$ while private sector banks it was close to $4 \%$.

The magnitude of NPAs in India is alarming, it's actually like a high bread financial cancer in nation economic health (Zafar et. al, 2013). The author has also studied about some aberrant methods to reduce NPA like credit appraisals and monitoring, timely inspection of credit, proper risk management before giving loans and advances, giving proper working conditions for AMCs and ARCs. (Joseph et al, 2014). 


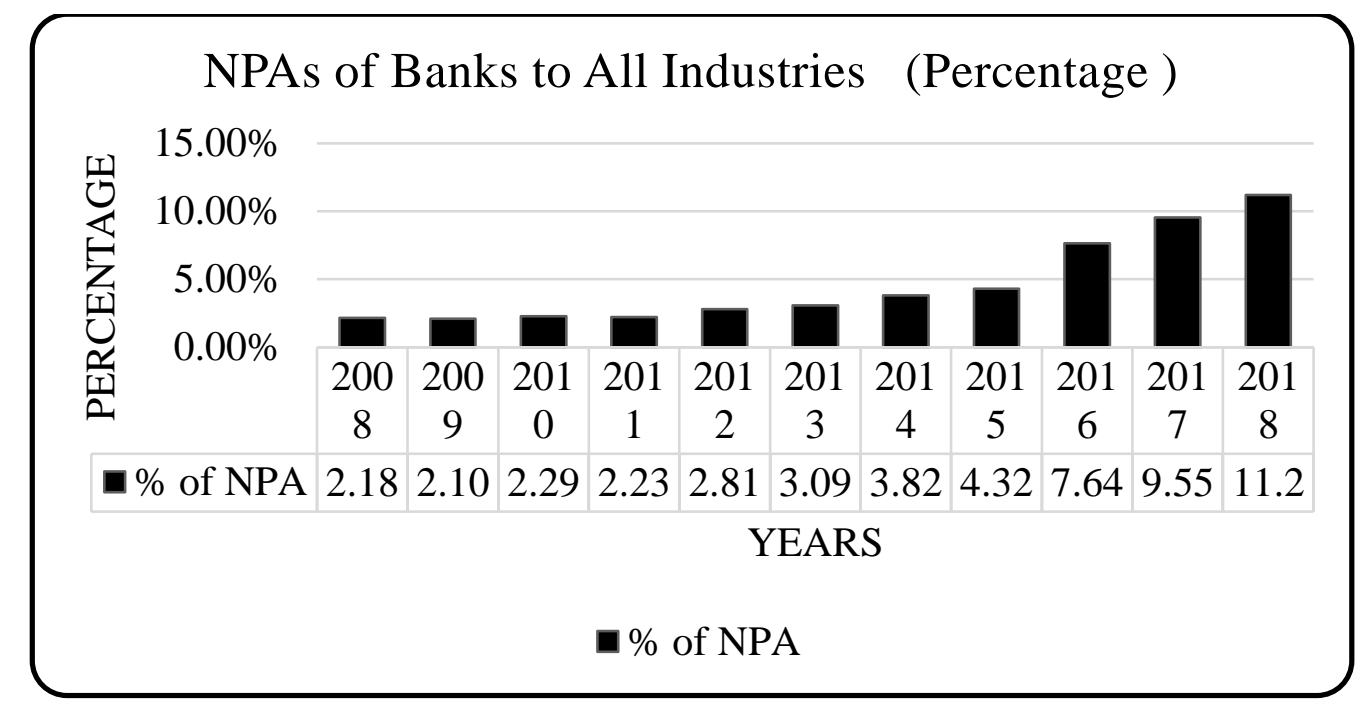

Figure 4: NPAs of the Public sector banks and private sector banks (Percentage)

The figure 4 is something very important and it shows why the Indian banking industry has been hitting the news line. The NPAs of the banks have been all time high and the growth has been tremendous. The FY 2007-08 shows the NPAs as 2.18\% which has been increasing year on year basis. The increase in NPAs in $2015-16$ was $76 \%$ as comparison to the previous year and as the number it stood as $7.64 \%$ of the total loans given, which is an area of concern for the banks. The growth in NPAs did not stop and it went on increasing year on year, breaking all the records and in the FY 2017-18, it stood as 11.20\%. The share of private sector banks in the NPAs in FY 2017-18 was close to $4 \%$ while for public sector it was around $14 \%$. The lowest NPAs were reported in the year 2009 where the figure stood as $2.10 \%$ in these 10 years.

\section{INSOLVENCY AND BANKRUPTCY CODE, 2016}

There were many processes to deal with the insolvency and recovery of the loans from the companies such as Sick Industrial companies act, 1985, Securitization and reconstruction of financial assets and enforcement of security interest act, 2002 etc. but all these act failed to provide a proper mechanism to deal with the recovery of the loan. The banks have had joint lenders forum, corporate debt restructuring (CDR), and strategic debt restructuring (SDR) to deal with stressed assets. The primary reasons was that these processes existed in standalone manner, legal delays etc. which further led to the deterioration in the quality of assets and claims. This resulted in the increasing NPAs.

IBC was passed in the parliament on 11 May, 2016 where it will override all the existing provisions relating to the insolvency and bankruptcy. IBC is one of the major reforms which has brought respite to the lenders by having a transparent, time-bound resolution of the sick units. IBC works under the umbrella of IBBI (Insolvency and bankruptcy board of India) through NCLT (National company law tribunal). IBBI is the apex body for IBC and will also 
be in involved in the administration and supervision of insolvency professionals and information utilities.

The pillars of IBC are equality, transparency, resolution and pace (report of EY). The mandate of $180+90=270$ days is what makes the IBC as one of the most Significant reforms of the recent times which is aimed to bring the credit discipline among the borrowers. Though in reality the threshold of 270 days has been breached due to various operational and procedural delays, still it is supposed to be back on track in coming times. It has been only 2 years since IBC started working and the number of cases which has been registered under this and resolution given by IBC is what make this act as the game changer in the economy. It operates through 11 branches of NCLT across India.

IBC makes the distinction between operational creditor and financial creditors (having of default of Rs. 1 lakh or more) and allows any one of them to file the case for bankruptcy. It works on the waterfall system for deciding the order of payment to the various parties. The government dues rank after the financial debt of unsecured creditors while these were ranked higher in companies act, 2013.

The main differentiating aspect of the IBC is that it depends heavily on administrative structure to ensure flow of information and resolution of issues in a time bound manner. It gives the creditors the prerogative right to decide over the Law about the decision to liquidate or revive. If the corporate resolution plan is not passed or not approved, NCLT shall order for liquidation of the company or make a public announcement.

\begin{tabular}{|c|c|c|c|c|c|c|c|}
\hline \multirow[b]{2}{*}{ Quarter } & \multirow[b]{2}{*}{$\begin{array}{c}\text { CIRPs at the } \\
\text { beginning of the } \\
\text { quarter }\end{array}$} & \multirow[b]{2}{*}{ Admitted } & \multicolumn{4}{|c|}{ Closure by } & \multirow[b]{2}{*}{$\begin{array}{l}\text { CIRP at the } \\
\text { end of quarter }\end{array}$} \\
\hline & & & $\underset{\text { d }}{\text { Appeal/Review/Settle }}$ & $\begin{array}{c}\text { Withdrawal } \\
\text { under section 12A }\end{array}$ & $\begin{array}{c}\text { Approval of } \\
\text { Resolution plan }\end{array}$ & $\begin{array}{l}\text { Commencement of } \\
\text { liquidation plan }\end{array}$ & \\
\hline Jan-Mar, 2017 & 0 & 37 & 1 & 0 & 0 & 0 & 36 \\
\hline April-June, 2017 & 36 & 129 & 8 & 0 & 0 & 0 & 157 \\
\hline July-Sept, 2017 & 157 & 232 & 18 & 0 & 2 & 8 & 361 \\
\hline Oct.-Dec, 2017 & 361 & 147 & 38 & 0 & 7 & 24 & 439 \\
\hline Jan-Mar, 2018 & 439 & 195 & 20 & 0 & 11 & 59 & 544 \\
\hline April-June, 2018 & 544 & 245 & 20 & 1 & 14 & 50 & 704 \\
\hline July-Sept, 2018 & 704 & 235 & 30 & 26 & 32 & 83 & 768 \\
\hline Oct.-Dec, 2018 & 768 & 264 & 7 & 36 & 13 & 78 & 898 \\
\hline Total & & 1484 & 142 & 63 & 79 & 302 & 898 \\
\hline
\end{tabular}

Table 1: Status of cases filed under IBC, 2016 (Source: IBBI report)

The table 1 shows the progress of IBC in last 2 years, since it started functioning. The total number of cases which have filed under IBC as on Dec., 2018 were 1484. The total number of cases which were appealed, reviewed or settled were 142 while 63 cases were withdrawn, 79 cases were approved for resolution plan while for 302 cases liquidation commenced. The total number of cases which were outstanding as of December, 2018 were 898 . There were around $30 \%$ cases ( 275 in total) where the number of days were more than 270 while other cases were less than 270 days. Looking at the number of cases which were filed and which were resolved, 
it does not appear to be a major success in terms of insolvency. There were many cases which were not resolved within the given mandatory time period of 270 days as well. However, this should be seen as beginning of an era rather than commenting on the success of the IBC.

The number of cases filed under NCLT were for 123 companies under the sector metal and Iron and steel sector is a part of metal sector. The total debt due to these 123 companies stood at 1540 billion. As on May, 2018.

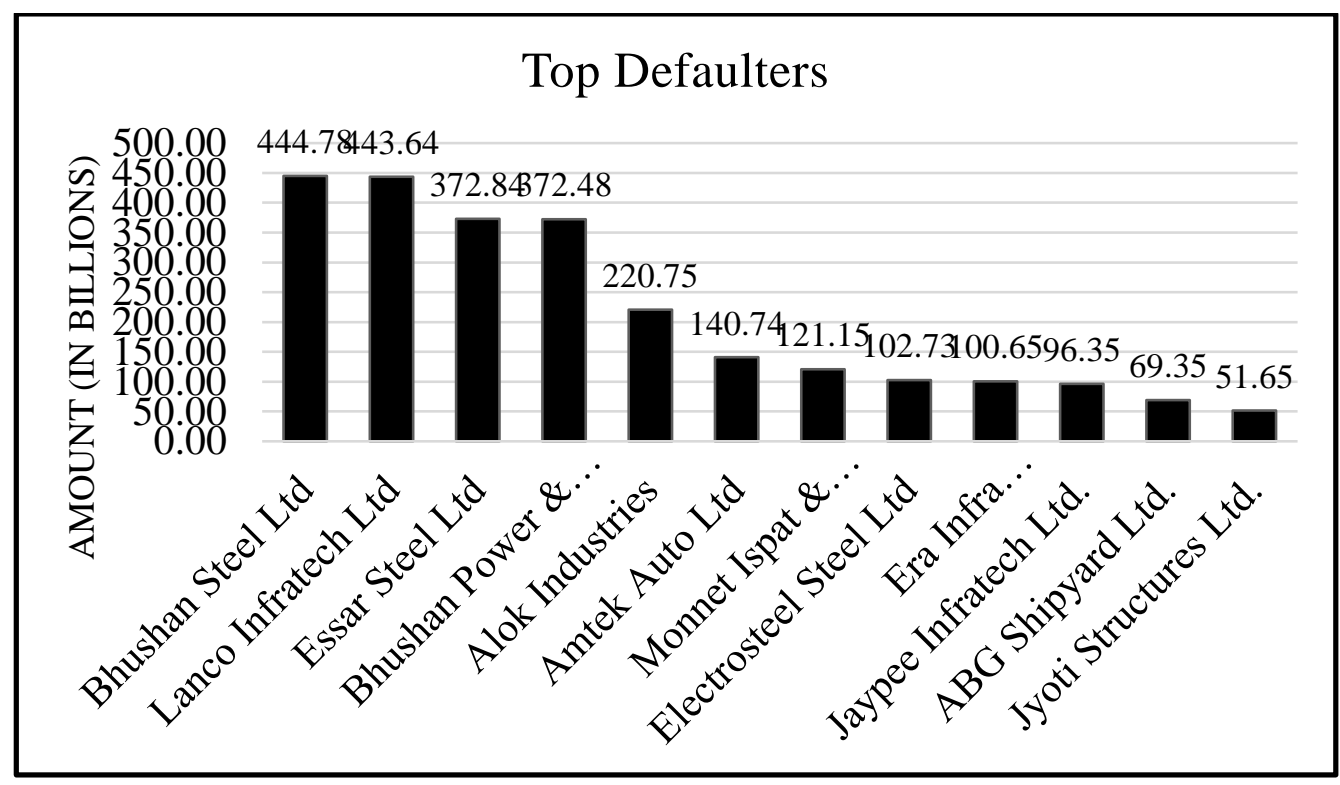

Figure 5: Top defaulter under IBC, 2016

The figure 5 shows the default amount of companies which are in the top list. As per RBI, there are 12 companies which constitute $25 \%$ of the gross NPAs. The above graph shows the list of top 12 defaulters as on September, 2017 and out of those 12 companies 5 companies are from Iron and steel sector.

\begin{tabular}{|l|c|c|c|}
\hline Name of Corporate Debtor & $\begin{array}{c}\text { Amount } \\
\text { Admitted (Rs. In Billion.) }\end{array}$ & $\begin{array}{c}\text { Amount } \\
\text { Realized (Rs. In Billion.) }\end{array}$ & $\begin{array}{c}\text { Realization as } \\
\text { percentage of Claim }\end{array}$ \\
\hline Electrosteel Steels Ltd & ₹ 131.75 & $₹ 53.20$ & $40.38 \%$ \\
\hline Bhushan Steel Ltd & $₹ 560.22$ & ₹ 355.71 & $63.49 \%$ \\
\hline Monnet Ispat \& Energy Ltd. Pvt. Ltd. & ₹ 110.15 & ₹ 28.92 & $26.26 \%$ \\
\hline Amtek Auto Ltd & ₹ 126.05 & ₹ 43.34 & $34.38 \%$ \\
\hline
\end{tabular}

Table 2: Status of Top defaulter under IBC, 2016 (source: IBBI report)

RBI has directed these 12 companies to be referred to the IBC, 2016 for bankruptcy proceedings. Bhushan Steel was the first one to be referred and NCLT approved Tata Steel resolution plan for Bhushan steel in May, 2018 where Tata Steel offered to pay upfront Rs. 35,200 crores to the 
lenders. Out of those 12 accounts which were referred by RBI, 4 were approved and the above table shows the status of recovery. The maximum recovery was made in the case of Bhushan steel where $36.51 \%$ was the hair cut for the lenders but it also brought a respite that $63.49 \%$ was recovered.

\begin{tabular}{|c|c|c|c|c|}
\hline S.No. & Name & $\begin{array}{c}\text { Defunct } \\
\text { (Yes/No) }\end{array}$ & $\begin{array}{c}\text { Date of } \\
\text { Commencement of } \\
\text { CIRP }\end{array}$ & Date of Liquidation order \\
\hline 1 & R.V.Steel and Power Pvt. Ltd. & Yes & $27-09-2017$ & $21-06-2018$ \\
\hline 2 & Jai Bhavani Steels Enterprises Ltd. & Yes & $02-04-2018$ & $23-07-2018$ \\
\hline 3 & Impex Steel Ltd. & Yes & $16-03-2018$ & $18-09-2018$ \\
\hline 4 & Ramdas Ispat and Metal Pvt. Ltd. \&Ors & Yes & $06-04-2018$ & $22-10-2018$ \\
\hline 5 & Kamineni Steel and Power India Pvt.Ltd. & Yes & $10-02-2017$ & $26-10-2018$ \\
\hline 6 & Vandana Energy \& Steels & Yes & $20-10-2017$ & $31-10-2018$ \\
\hline 7 & Ramanand Steels Ltd & Yes & $20-03-2018$ & $02-11-2018$ \\
\hline 8 & Pavai Alloys \& Steels Pvt ltd & Yes & $29-06-2018$ & $03-12-2018$ \\
\hline 9 & Gangadhar Steel Ltd & No & $29-08-2017$ & $11-12-2018$ \\
\hline 10 & Ispat Energy Ltd. & Yes & $25-04-2018$ & $14-11-2018$ \\
\hline 11 & Gee Ispat Pvt. Ltd. & Yes & $24-08-2017$ & $05-10-2018$ \\
\hline
\end{tabular}

Table 3: Status of liquidation of Iron and steel companies under IBC, 2016 (source: IBBI report)

The above table shows the iron and steel companies which ended into liquidation as of December, 2018. There are 11 companies belonging to iron and steel sector which went for liquidation. There are companies such Kamineni Steel, Vedanta Energy and steel, and Ramanand Steel, Gangadhar Steel where the resolution period was more than 270 days. The resolution period was less than 270 day in other cases.

\section{CONCLUSION AND SUGGESTIONS}

Mounting NPAs are a major concern for any bank, economy and country and more important for a country like India which is on growth phase. India has been recognized from developing economy to emerging economy and in order to sustain the long term growth, it is important that the industry and businesses grow. This can be achieved by having a proper economic policy of giving and extending credit to those who need this and ultimately help the country to grow, however the default rate for these loans has been on an increasing trend. India has had many other ways to deal with these NPAs right from BIFR Act, 1985 to SARFAESI Act, 2002 to S4A 2016 but nothing seem to working in the desired way. This paved way for IBC, 2016.

It has been only 2 years since IBC, 2016 has been implemented and it is considered to a revolutionary not only in India but globally. IMF and world bank has also reacted positively to 
the implementation of IBC, 2016 in India and it has resulted in the improvement of ranking of India, in terms of ease of doing business.

IBC, 2016 does not comes with a magic wand where the problems of NPAs which existed since year, can be solved by a wand. This is definitely beginning of a new era in the whole economy where there is shift from debtors to creditors and creditor is given supremacy and he takes control of debtor's assets.

The result of the IBC, 2016 is to be seen and it has been just 2 years since IBC is implemented. Based on the performance of IBC and others reports, it is found that the IBC works with 11 branches of NCLT, which is too low considering the number of cases pending. The number of cases which are pending with IBC as on December, 2018 are 898 and $30 \%$ of the cases are more than 270 old. It should not happen the basic strength of the IBC, timely resolution, gets defeated. IBC does not cover cross border insolvency as of now however it gives guidelines to government for the same. UNCITRAL model law of Cross-border insolvency should be adopted in India as well as this is being adopted by more than 41 countries globally. There is a greater need to adopt technology in the whole process and the process should be online from the perspective of creditor who can see the progress of the case online. This will also reduce the manual work and delays in the system.

\section{REFERENCES}

[1] Balasubramaniam, C. S. (2012). Non-performing assets and profitability of commercial banks in India: assessment and emerging issues. National Monthly Refereed Journal Of Research In Commerce \& Management, June, Volume, 1, 41-52.

[2] Chatterjee, S., Shaikh, G., \& Zaveri, B. (2017). Watching India's insolvency reforms: a new dataset of insolvency cases (No. 2017-012). Indira Gandhi Institute of Development Research, Mumbai, India.

[3] Chaudhary, K., \& Sharma, M. (2011). Performance of Indian public sector banks and private sector banks: A comparative study. International journal of innovation, management and technology, 2(3), 249.

[4] Das, S., \& Dutta, A. (2014). A Study on NPA of Public Sector Banks in India.

[5] Franks, J. R., Nyborg, K. G., \& Torous, W. N. (1996). A comparison of US, UK, and German insolvency codes. Financial Management, 86-101.

[6] Guleria, K. (2016). A Study of Non-Performing Assets of Public Sector Banks in India. International Journal of Research in Engineering, IT and Social Sciences, 6(4), 26-34.

[7] Joseph, A. L., \& Prakash, M. (2014). A study on analyzing the trend of NPA level in private sector banks and public sector banks. International Journal of Scientific and Research Publications, 4(7), 1-9.

[8] Mittal, R. K., \& Suneja, M. D. (2017). The Problem of Rising Non-Performing Assets in Banking Sector in India: Comparative Analysis of Public and Private Sector Banks. Journal Homepage: http://www. ijmra. us, 7(7).

[9] Miyan, M. (2017). A Comparative Statistical Approach towards NPA of PSU and Private Sector Banks in India. International Journal of Advanced Research in Computer Science, 8(1). 
[10] Srinivas, G., \& Vadde, S. (2016). The Indian Steel Sector: Development and Potential (No. id: 11334).

Srivastava, V., \& Gupta, S. K. (2010). A Study on Non-Performing Assets of Indian Banks. GYANPRATHA-ACCMAN Journal of Management, 5(2).

[11] The Quarterly Newsletter of the Insolvency and Bankruptcy Board of India January March 2018 | Vol. 6

[12] The Quarterly Newsletter of the Insolvency and Bankruptcy Board of India October December, 2018 | Vol. 9

[13] Report on Trend and Progress of Banking in India for the year ended June 30, 2018 submitted to the Central Government in terms of Section 36(2) of the Banking Regulation Act, 1949

[14] Report of EY "The Insolvency and Bankruptcy Code,2016 An overview July 2016"

[15] Report of PWC" Decoding the Code: Survey on Twenty-One Months of IBC in India"

[16] Report of EY "Insolvency and Bankruptcy Code The journey so far and the road ahead December 2018"

[17] Zafar, S. M. T., Maqbool, A., \& Khalid, S. M. (2013). Non-performing assets and its impact on Indian public sector banks. International Journal of Marketing, Financial Services \& Management Research, 3(2), 68-87.

[18]

https://www.ibbi.gov.in/uploads/publication/QUARTERLY_NEWSLETTER_FOR_OCT_ DEC_2019.pdf

[19] https://m.rbi.org.in/Scripts/PublicationsView.aspx?id=18523

[20]

https://ibbi.gov.in/uploads/publication/QUARTERLY_NEWSLETTER_FOR_OCT_DEC_ 2019.pdf

[21] https://rbi.org.in/Scripts/Data_Sectoral_Deployment.aspx

[22] http://www.ijsrp.org/research-paper-0817.php?rp=P686701

[23] http://www.iibf.org.in/documents/IRAC.pdf

[24] https://www.financialexpress.com/industry/banking-finance/indias-bad-loans-here-isthe-list-of-12-companies-constituting-25-of-total-npa/903396/ 